\title{
Factors Affecting Student Satisfaction in Distance Learning: A Case Study
}

\author{
Muhammad Rizwan ${ }^{1}$, Iffra Iftikhar ${ }^{2}$
}

\begin{abstract}
Generally, In Pakistan, people perceived that the quality of distance learning education is poor. Therefore, we decided to study to see if it's only people's opinion or legend. The study aims to analyze the association between instructor performance (IP), student-instructor interaction (SII), course evaluation (CE), and student satisfaction (SS) variables in distance education by taking Virtual COMSATS as a Case study. The target population of this research was the COMSATS (VIRTUAL CAMPUS). Students out of which 251 graduate and undergraduate students were selected as sample for current research. The purpose of this research study was to understand the key factors affecting student satisfaction in distance learning. Researchers also collect information through primary data using a survey questionnaire distributed through email to all the students of VCOMSAT. The literature review found that in distance learning education, student satisfaction is based on instructor performance, student-instructor interaction, course evaluation, Learning management system use, instructor attitude, etc. From the literature review, we found that course evaluation and instructor performance is very important for student satisfaction in distance learning. Researchers need to compare student's satisfaction with the subject wise. A comparison of practical subjects and without practical subjects needs to identify with student satisfaction. There is also required to compare lecturer motivation with student satisfaction and performance. Future research is also needed to compare the satisfaction of rural areas and urban areas students in distance learning education and the need to compare them with traditional education.
\end{abstract}

Keywords: Distance learning, e-learning, student satisfaction, instructor performance, Course evaluation, student instructor interaction.

Distance education is defined as a method of larning in which teachers and students are isolated physically. In this method, teachers and students can interact with each other from a remote location. Students can interact with instructors from any place, any location and any time. The new delivery method and platforms of education are telephones, radio, postal services, television (TV), printing machines, and the internet. These methods are used in distance education.

These days the internet has turned into a productive educational resource and a new instructive experience for students, which were impractical prior. Now a day's web and data innovation has changed the substance of education. In advanced education, web instructions are quickly getting to be reasonable and developing as an open door for conveying training on the web. Now universities can give distance education chances to students who have limited access to advance educational opportunities.

According to Sher (2008), the development of online education projects has been invigorated by the progress of the web and present-day information innovation (IT) that changed the substance of training.

The internet has turned into an essential, instructive means. It offers new educational experiences for understudies that were not prior conceivable. Because of the progression of the most recent innovation, online training has ascended as a choice or, if nothing else, a considerable supplement to routine strategy for learning and teaching (Lewis \& Waits, 2004).
This study was taken to explore the most recent issue of COMSATS VIRTUAL CAMPUS students in distance education (DE). In Pakistan, most of the people perceive that the quality of distance learning education is poor. Therefore, we decided to carry out this research study to see if it's people's judgment or if there are any authenticities about poor outcomes of students in distance education compared to traditional education students. This study observes the association between student satisfaction and different independent variables in distance education by taking Virtual COMSATS as a Case study. We asked different questions to COMSATS VIRTUAL CAMPUS students about their satisfaction regarding instructor performance, student-instructor interaction, and course evaluation.

Secondly, this study was carried out by keeping in view the increasing demand for distance education in Pakistan.

\section{Research Question}

To find the relationship between Instructor performance, student instructor interaction, course evaluation and student satisfaction three research questions were used to guide this study.

- Does course evaluation influence student satisfaction?

- How student-instructor interactions affect the student satisfaction?

- Does Instructor performance have any influence on student satisfaction?

${ }^{12}$ Senior Lead Generation Executive, Department of Mass Communication, Lahore Leads University, Pakistan, mr78181@gmail.com 
Objective of the study was to understand and explore the relationship between student-instructor interaction, instructor performance, and course evaluation and student satisfaction.

\section{Significance of the Study}

This study was carried out by keeping in sight the rising demand for distance education in Pakistan. Presently there are limited degree-awarding universities in Pakistan which are providing distance education i.e., COMSATS VIRTUAL CAMPUS, Virtual University (VU), and Allama Iqbal Open University (AIOU). In Pakistan, most of the people perceive that the quality of distance learning education is poor. Therefore, we decided to carry out this research study to see if it's people's judgment, or there are any authenticities about the unfortunate outcome of students in distance education as corresponding to traditional education students. This study aims to observe the association between student satisfaction and different independent variable in distance education by taking Virtual COMSATS as a Case study.

\section{Concept of E-learning}

Electronic learning (e-learning) is the utilization of information technology (IT) to distribute information for training and education (Aixia and Wang, 2011). Different methods of electronic learning are virtual learning, web-based learning, circulated learning, and network-based learning. These are referring to education processes that are utilized in information and communication technology. According to Naidu (2006), electronic learning comprises a lot more than virtual learning, distributed learning, web-based learning, and online learning. In e-learning, "e" stands for dictionary word "electronic" all education activities are included in e-learning that is carried out by a group or individual working offline or online, standalone pc, or networked or other electronics devices (Naidu,2006). In recent years, elearning society is seen as vital to the future of education and the help of deep-rooted learning. By empowering learners to learn at whatever time and any place, enthusiasm for it have been developing for organizations to prepare their workers and academic institutions to set up web-course learning frameworks. Adaptable access refers to get to and utilization of data and assets at once, place, and place that is suitable and helpful to individual learners as opposed to the educator and the instructive association. Versatile access alludes to get to and usage of information and resources at once place that is helpful and suitable for individual learners rather than the instructor and the educational affiliation. It permits distance learners, to be in full or part-time vocation furthermore can learn at one place that is suited for their accommodation.

\section{Learner Satisfaction in E-learning}

E-learning is a new example of higher education in modern education. After initial experience, many students stop their online learning, and students' early apparent fulfillment with technologybased e-learning will decide whether they will continuously utilize the system.

\section{Factors that influence student satisfaction}

There are different factors that influence on student's satisfaction. Instructor-related factors, student related factors and technology related factors

\section{Instructor-related factors}

According to Rockwell et al., (1999); Sloan Consortium, (2006), faculty members are satisfied when they are known for the work that they are doing. Faculty satisfaction is positively influenced when faculty believes that they can promote positive student outcomes (Rockwell et al.; 1999; Sloan Consortium, 2006). Other intrinsic motivators include intellectual challenge, selfgratification, and an interest in technology (Panda and Mishra, 2007; Rockwell et al., 1999). Faculty satisfaction decreases when they experience difficulties with technology and tools access. According to Finally-Neuman, 1994; Williams and Ceci, 1997, the teacher is an important predictor in course satisfaction. The instructor becomes a motivator and facilitator for the student. Instructor feedback is a critical factor in satisfaction with students. DeBourgh, (1999); Hiltz, (1993), Instructor performance and his/her availability and response time highly associated with student satisfaction.

\section{Student-related factors}

In online, there is an open door for students to interface in exceedingly intelligent correspondence with the teacher and their companions that is inspiring to faculty (ADEC, n.d.; Betts, 1998; Sloan Consortium, 2006). There is a reason that the workforce like to show online is that online instruction bears access to advance education more different student populations (ADEC, n.d; Betts, 1988; Rockwell et al.; 1999; Sloan Consortium, 2006). As indicated by Bower, (2001), some employees express worry about restricted communication with students where they never meet face-to-face with the student. In this research, a positive correlation between student performance and faculty satisfaction is built up. The level of personnel fulfillment is high in which course student execution is better (Frederickson et al., 2000; Hartman et al., 2000).

\section{Technology-related factors}

Chen \& Huang (2012) expressed that understanding student mentalities can extend e-learning frameworks and address student issues, which should further build the effect of learning and improve fulfillment with the learning process. Student fulfillment with e-learning situations was inspected in a few studies (Sasidharan, Santhanam, 2008; So \& Brush, 2008; Wu and Hsia, 2010; Zhu, 2012). The conducive learning environment and execution desires influence student fulfillment, and execution desire gives the best commitment to learning fulfillment. Teachers and students will hold an inspirational state of mind towards elearning on the off chance that they realize that it would offer then some assistance with improving their showing and learning adequacy and effectiveness (Rehmat et al., 2012; Wu, Tennyson, \& Hsia, 2010).

\section{Interaction in Distance Learning}

The communication process between humans and non-human, for example, human-computer interaction, is called interaction. According to Moore, 1989; in distance education three types of interaction exist that are: (a) learner-to-learner interaction (b) learner-to-content interaction (c) learner-to-instructor interaction. Benbunan-Fich, et al., (2005) proposed the online interaction theory for an online learning environment that defines the 
procedure and results in online learning. 3P model especially applies to both classroom and online learning. Benbunan-Fich, et al. (2005) 3P models consist of 3 processes (a) input (b) learning process and (c) output. The learning process level of interaction influences the effect of input on outputs; for example, the learning process plays an essential role between inputs and outputs. In learning procedure level of interaction impact on the impact of contribution on yields, for example, learning procedure assumes an essential part among inputs and yield. Benbunan-Fich et al., (2005) representation spotlight on the part of the communication element at the phase of learning method with a specific end goal to expect a yield of learning. Model of Biggs (1979); focus on student ways to deal with instructing in the learning system in the desire of output of learning. Student, instructor, technology, and course are Inputs factors that influence on online learning satisfaction. All these factors are moderator variables that influence the learning techniques that are adapted for a unique subject. If the instructor has no experience teaching online or designing online courses, he will not be able to take an online class effectively.

\section{Student satisfaction from student-instructor interaction:}

As indicated by numerous analysts, online training's overall achievement and effectiveness rely on the interaction, which is a vital component to student learning (Fresen, 2007; Northrup, 2001; Moore, 1993). Along with these lines, Volery et al.; (2000) recommended that the teacher may give a cooperation mark in mind the end goal to support students' interaction. Besides, the instructor ought to have the capacity to comprehend the students' various ways, include them in online talks, and urge the student to student interaction (Durling, Johnson, Cross, 1996).

In the distance, education interaction is a vital part of learning. In education, student-instructor interaction is hence typical that is an essential requirement for learning (Garrison and Anderson, 1995; Picciano, 2002. Three types of interaction reported by Moore (1989) are student to student, student to content, and student to instructor. All these interactions are important for the satisfaction of students in distance education (Young \& Norgard, 2006). Interaction quality between students and their instructor, and course content and student-student is important. Student-instructor interaction was the most important factor in online studies (Battalio, 2007). Face to face meetings with each learner does not have the advantage for an instructor in online learning.

\section{Student satisfaction from Course Evaluation:}

Michailidou and Economides, (2003) state that the change of an online domain permits understudies to take an interest in the informative techniques by playing with the lesson objects. Especially the subjects that include dialog, conceptualizing, and reflection are most appropriate to the online organization (Wells, 1992). A standout amongst the most vital elements of distance education is the student's interaction through course discussions (Shea, Swan, Maher, and Pickett, 2000). Irani, (1998) course plan should have a loaded correspondence perspective, because the correspondence level sensibly affects understudies' learning, fulfillment, and support in web courses.
Swan et al. (2000) conducted that student favored reliable course structure with the goal that route does not change starting with one course then onto the next. According to Levin et al., (1990), understudies see that dialog in separation learning is most impartial and fair than up close and personal talks. Students got to be disappointed when their courses were inadequately outlined. Similarly, educators did not take an interest or reacted to address a constrained time (Yang and Cornelius, 2004; Perris and Zeng, 2004). As per Sahin (2007), there might be a probability that this dissatisfaction might unravel into a poor learning result. In this manner, in online education, receiving student's criticism about their requirements and inclinations is essential for the fruitful configuration and execution of this atmosphere.

Swan (2001) reported three components: communication with instructor and dynamic exchange among course members and clarity outline, which altogether impacted the satisfaction of students in distance learning courses.

\section{Methodology}

This study was focused on critical factors affecting student satisfaction in distance learning education. In this study, student satisfaction was taken as a dependent variable, and Student instructor interaction (SII), Instructor performance (IP) and Course evaluation (CE) was taken as independent variable that impact on student satisfaction in distance learning education as COMSATS VIRTUAL CAMPUS was taken as a case study. In this chapter, the procedure was defined that were used in this study.

\section{Conceptual Framework}

The conceptual model is shown below that was made based on literature review and introduction.

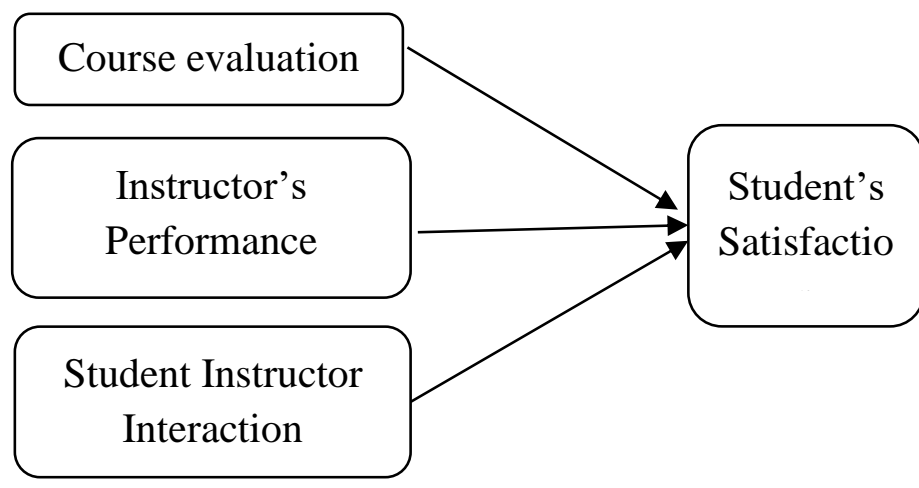

Adopted from Ali. A., \& Ahmad I., (2011)

Figure 1: Conceptual Framework Research Model

Research Hypothesis

The following hypotheses have been developed from the literature review:

H1: Instructor performance will be positively related to the student's satisfaction.

H2: Student-instructor interaction will be positively related to the student's satisfaction.

H3: Course evaluation will be positively related to the student's satisfaction.

\section{Research Method}

There are different types of research data: 1- Primary data 2Secondary data. Primary data is original data that is first-hand data 
collecting through surveys and observation. Secondary data is based on existing research, newspaper, academic books, and journals. This study contains primary data that is collected through quantitative research. The questionnaire survey is the most popular and most useful instrument in quantitative research. This method has some advantages to other research methods like observation, interview. In this method, the researcher can gather a lot of data in less time frame. This method is also cost-efficient compare to others. In this study, we used an online questions survey for data gathering.

Sampling is defined as identifying a group of participants from the target population that was used in research. Sample data is collected for research because it is not possible to get data from the whole population. The population size of this research was all the students of COMSATS VIRTUAL CAMPUS, but sample data was collected from 251 students. There are different sampling methods like probability sampling and non-probability sampling, and every technique has some advantages and disadvantages. In this study, we used probability sampling technique. For the questionnaire, we created an online Google form. For accurate data collection, we create password-protected form only COMSATS VIRTUAL CAMPUS student can fill the form, and one attempt is allowed to fill the form. After creation the form, we generated the web link and sent this link to the admin of virtual COMSATS for sending the email to all COMSATS VIRTUAL CAMPUS students. Admin received the mail and sent it to all COMSATS VIRTUAL CAMPUS students because the only moderator of the list can send the email to student groups. We received a response of 251 undergraduate and graduate students of COMSATS VIRTUAL CAMPUS from session FA12 to SP15. Students' responses were collected in excel form and download the excel file and used for further analysis.

\section{Research Instrument}

All questions were used based on Arbaugh's (2000) work and Ali. A., \& Ahmad I., (2011). The questionnaires were comprised of 26 items. It was contained in two parts. The first part contained demographic information, and the second part contained the variables and their items. The demographic profile included four items: Gender, age, student type, and educational level. Student satisfaction was measured with six questions, student-instructor interaction with five questions, instructor performance with nine questions, and course evaluation with six questions. Each item is measured on five-point Likert-type scales, ranging from 1(strongly disagree) to 5 (strongly agree).

Students' satisfaction was measured with six-item adapted from Arbaugh (2000) study. Focuses of these questions were on student satisfaction and their belief in its quality and objective to take the course in future distance education. All these items were measured using five-point Likert scale methods with response option 1(strongly disagree) to 5 (strongly agree).

Student's instructor satisfaction was measured with five items adapted from Ali. A., \& Ahmad I., (2011) study. These five items were measured using five points Likert scale method with response option 1 (strongly disagree) to 5 (strongly agree).
Instructor performances were measured with nine items adapted from Ali. A., \& Ahmad I., (2011) study. These nine items were measured using five points Likert scale method with response option 1 (strongly disagree) to 5 (strongly agree).

Course evaluations were measured with six items adapted from Ali. A., \& Ahmad I., (2011) study. These six items were measure using five points Likert scale method with response option 1 (strongly disagree) to 5 (strongly agree).

\section{Data analysis and discussions}

Data analysis was used to analyze collected data using different tools and techniques. In this research, the collected data were analyzed using descriptive analysis, correlation analysis, and regression analysis and cross-tabulation between different variables. The correlation coefficient was used to measure the relationship between the dependent and independent variables. Cross tabulation was used to measure the statistics of one variable compared to others. This study was focused on critical factors affecting student satisfaction in distance learning education. In this study student satisfaction was taken as dependent variable Student instructor interaction (SII), Instructor performance (IP) and Course evaluation (CE) was taken as independent variable that impact on student satisfaction in distance learning education.

\section{Reliability Analysis}

Table 2 reveals that Cronbach alpha was used to verify the reliability of the data after collecting the data. Student satisfaction and its determinants have the right internal consistency. The researcher showed that the scale was reliable because the Cronbach alpha was $0.877,0.885,0.929$, and 0.897 are higher than 0.8 and showed internal consistency in the scale and is applied to the research model.

\section{Descriptive Analysis}

Table 1 reveals the students' demographic profile. It reveals that $187(74.5 \%)$ male and $64(25.5 \%)$ female students responded to the sample out of 251. Full-time students were $65(25.5 \%)$, and part-time students were $186(74.1 \%)$ who participated in the survey.

Table 1: Demographic Sample

\begin{tabular}{llcc}
\hline \multicolumn{1}{l}{ Variable } & & $\mathbf{N}$ & \% \\
\hline Gender & Male & 187 & 74.5 \\
& Female & 64 & 25.5 \\
Student Type & Full time & 65 & 25.9 \\
Age & Part time & 186 & 74.1 \\
& $20-25$ & 65 & 25.9 \\
& $26-30$ & 93 & 37.1 \\
\multirow{5}{*}{ Academic Program } & $31-35$ & 43 & 17.1 \\
& $36-40$ & 29 & 11.6 \\
& Above 40 & 21 & 8.4 \\
& Bachelor & 30 & 12 \\
& Master & 180 & 71.7 \\
\hline
\end{tabular}

The result reveals that 37 percent responded age was 26-30 years, and only 8.4 percent of student's age was above 40 years. Master program students $(71.7 \%)$ were higher than bachelor $(12 \%)$ and other students $(16 \%)$ in distance education. Furthermore, most of the respondents were master's program students. Overall, this table showed that most of the respondents were male, part-time, and master program students. Other details are mentioned in table 1. 
Table 2: Descriptive Statistics

\begin{tabular}{lcccc}
\hline Variable Name & Items & Mean & $\begin{array}{c}\text { Std. } \\
\text { Deviations }\end{array}$ & $\begin{array}{c}\text { Cronbach } \\
\text { Alpha }\end{array}$ \\
\hline Student Satisfaction & 6 & 3.655 & 0.889 & 0.877 \\
Student-Instructor & 5 & 3.298 & 1.0162 & 0.885 \\
Interaction & & & & \\
Instructor Performance & 9 & 3.537 & 0.944 & 0.929 \\
Course evaluation & 6 & 3.817 & 0.895 & 0.897 \\
\hline
\end{tabular}

Table 2 also reveals the means and standard deviation results of all dependent and independent variables. The means of student satisfaction, Student instructor interaction (SII), Instructor performance (IP) and Course evaluation (CE) was greater than 3.0 it showed respondents gave positive response.

\section{Correlation Analysis}

Using correlation matrix researchers find the results of hypothesis based on the below table.

Table 3: Correlation Analysis

\begin{tabular}{lllll}
\hline & SS & SII & IP & CE \\
\hline Student satisfaction & 1 & & & \\
Student Instructor Interactions & $.463^{* *}$ & 1 & & \\
Instructor Performance & $.620^{* *}$ & $.670^{* *}$ & 1 & \\
Course Evaluation & $.696^{* *}$ & $.453^{* *}$ & $.686^{* *}$ & 1
\end{tabular}

**. Correlation is significant at the 0.01 level (2-tailed).

Correlation was used to identify the relationship between dependent variable (student satisfaction) and independent variable (Student instructor interaction, instructor performance and course evaluation). The value of significance is represented as * $\mathrm{p}<0.05, * * \mathrm{p}<0.01$ and $* * * \mathrm{p}<0.001$

H1: Instructor performance will be positively related to the student's satisfaction.

Table 3 shows that the Pearson correlation value for instructor performance and student satisfaction was $r=0.620$, which was close to 1 . So, we can conclude that there is a strong positive relationship between instructor performance and student satisfaction. The value of significance was less than $\mathrm{p}<0.01$; it means there was a statistically significant relationship between instructor performance and student satisfaction.

H2: Student-instructor interaction will be positively related to the student's satisfaction.

Pearson correlation value for student-instructor interaction and student satisfaction was $r=0.463$, which is close to 1 . So we can conclude that there was a strong positive relationship between student-instructor interaction and student satisfaction. The value of significance was less than $\mathrm{p}<0.01$. it means there was a statistically significant relationship between student-instructor interaction and student satisfaction.

H3: Course evaluation will be positively related to the student's satisfaction.

Pearson correlation value between course evaluation and student satisfaction was $r=0.696$ that was close to 1 . So, we can conclude that there was a strong positive relationship between course evaluation and student satisfaction. The value of significance was less than $\mathrm{p}<0.01$. It means there was a statistically significant relationship between course evaluation and student satisfaction.

\section{Regression Analysis}

We calculate the hypothesis results using both linear and multiple regressions.

Table 4: Testing of Hypothesis

\begin{tabular}{lcccc}
\hline Variable name & R 1 & R 2 & R 3 & R 4 \\
\hline Student Instructor Interaction & $.414^{* * *}$ & & & $.082^{* * * *}$ \\
& -0.05 & & -0.053
\end{tabular}

\begin{tabular}{lcccc} 
Instructor Performance & & $.612^{* * *}$ & & $.205^{* * *}$ \\
& & -0.049 & & -0.071 \\
Course Evaluation & & & $.724 * * *$ & $.533^{* * *}$ \\
& & & -0.047 & -0.062 \\
Constant & $2.363^{* * *}$ & $1.538^{* * *}$ & $.927 * * *$ & $.662^{* * *}$ \\
& -0.175 & -0.182 & -0.188 & -0.19 \\
Test Diagnostic & & & & \\
$\mathrm{R}^{2}$ & 0.214 & 0.385 & 0.485 & 0.528 \\
Adjusted R & 0.211 & 0.382 & 0.483 & 0.522 \\
F Value & 67.869 & 155.636 & 234.478 & 92.097 \\
P value (sig) & 0 & 0 & 0 & 0 \\
\hline
\end{tabular}

Standard error in parenthesis, $* * * * *$ and $*$ represent statistical significance at 0.01 , 0.05 and 0.1 level.

Linear regression and multi regression were used to analyze the impact of independent variables on the dependent variable. In table 4, Column R1, R2, and R3 reveal the regression value of independent variables student-instructor interaction, instructor performance, and Course evaluation, respectively. Column R4 showed the multi regression value of all the variables.

Table 4 column $\mathrm{R} 1$ reveals that if there is one unit increase in student-instructor interaction, it leads to 0.414 unit increases in student satisfaction. This result is statistically significant at $0.01 \%$ level of significance. R2 shows that 21.4 percent variation independent variable is explained by student-instructor interaction. The probability of F stat is below $10 \%$, which shows that model is statistically correct.

Table 4 columns R2 reveals that if there is one unit increase in instructor performance, it leads to 0.612 unit increases in student satisfaction. This result is statistically significant at $0.01 \%$ level of significance. R2 shows that 38.5 percent variation independent variable is explained by instructor performance. The probability of F stat is below 10\%, which shows that our model is statistically correct.

Table 4 Regression 3 reveals that if there is one unit increase in the course evaluation, it leads to a 0.724 unit increase in student satisfaction. This result is statistically significant at $0.01 \%$ level of significance. R2 shows that 48.5 percent variation independent variable is explained by course evaluation. The probability of $\mathrm{F}$ stat is below $10 \%$, which shows that our model is statistically correct.

In the above table, column R4 showed the results of multi regression that if there is one unit increase in student-instructor interaction, instructor performance, and course evaluation, it leads to $0.082, .205$, and .662 respectively unit increase in student satisfaction. This result is statistically significant at $0.01 \%$ level of significance. The overall Probability of F stat is below $10 \%$, which shows that our model is statistically correct.

Table 5: Key Factors for Determining Student Satisfaction Instructor Performance

\begin{tabular}{|c|c|c|c|c|c|}
\hline Item number/question & SD\% & DA\% & N\% & A\% & SA\% \\
\hline $\begin{array}{l}\text { Overall instructors were } \\
\text { effective }\end{array}$ & 6.8 & 7.6 & 31.1 & 39.4 & 15.1 \\
\hline $\begin{array}{l}\text { The instructors were } \\
\text { available for consultation } \\
\text { during office hours or by } \\
\text { appointment. }\end{array}$ & 7.2 & 12.4 & 33.9 & 28.7 & 17.9 \\
\hline $\begin{array}{l}\text { The instructors stimulated } \\
\text { students learning }\end{array}$ & 6 & 16.7 & 33.1 & 30.3 & 13.9 \\
\hline The instructors treated all & 3.2 & 11.6 & 27.5 & 33.9 & 23.9 \\
\hline
\end{tabular}




\begin{tabular}{|c|c|c|c|c|c|}
\hline $\begin{array}{l}\text { The instructor treated all } \\
\text { students with respect }\end{array}$ & 5.6 & 4.4 & 17.1 & 41.8 & 31.1 \\
\hline $\begin{array}{l}\text { The instructor welcomed } \\
\text { and encouraged questions } \\
\text { and comments }\end{array}$ & 2.8 & 10 & 25.9 & 36.3 & 25.1 \\
\hline $\begin{array}{l}\text { The instructor presented } \\
\text { the information clearly }\end{array}$ & 4.8 & 9.6 & 24.7 & 38.2 & 22.7 \\
\hline $\begin{array}{l}\text { The instructor emphasized } \\
\text { the major points and } \\
\text { concepts. }\end{array}$ & 4.4 & 12 & 22.7 & 38.6 & 22.3 \\
\hline $\begin{array}{l}\text { The instructor } \\
\text { demonstrated knowledge of } \\
\text { the subject } \\
\text { Course Evaluation }\end{array}$ & 4 & 9.2 & 24.7 & 39.4 & 22.7 \\
\hline $\begin{array}{l}\text { Overall, I have valuable } \\
\text { learning experiences from } \\
\text { my courses }\end{array}$ & 4.8 & 8 & 19.1 & 43.4 & 24.7 \\
\hline $\begin{array}{l}\text { The assignments were } \\
\text { relevant and useful }\end{array}$ & 3.2 & 5.2 & 16.7 & 40.6 & 34.3 \\
\hline $\begin{array}{l}\text { Course materials were } \\
\text { relevant and useful }\end{array}$ & 4 & 6.8 & 13.9 & 43.4 & 31.9 \\
\hline $\begin{array}{l}\text { Expectations were clearly } \\
\text { stated either verbally or in } \\
\text { the syllabus }\end{array}$ & 2.8 & 11.2 & 21.5 & 39 & 25.1 \\
\hline $\begin{array}{l}\text { The testing and evaluation } \\
\text { procedures were fair. }\end{array}$ & 2.4 & 7.2 & 17.9 & 45.8 & 26.7 \\
\hline $\begin{array}{l}\text { The workload was } \\
\text { appropriate for the hours of } \\
\text { credit } \\
\text { Student Instructor Interact }\end{array}$ & 6.4 & 10 & 19.5 & 41 & 23.1 \\
\hline $\begin{array}{l}\text { The instructors encouraged } \\
\text { me to become actively } \\
\text { involved in the course } \\
\text { discussions }\end{array}$ & 11.2 & 16.3 & 24.7 & 31.5 & 16.3 \\
\hline $\begin{array}{l}\text { The instructors provided } \\
\text { me feedback on my work } \\
\text { through comments }\end{array}$ & 12.4 & 13.9 & 23.5 & 33.1 & 17.1 \\
\hline $\begin{array}{l}\text { I was able to interact with } \\
\text { the instructors during the } \\
\text { course discussions }\end{array}$ & 8.8 & 10.8 & 27.1 & 35.5 & 17.9 \\
\hline $\begin{array}{l}\text { The instructors treated me } \\
\text { individually }\end{array}$ & 8.8 & 17.9 & 21.1 & 34.3 & 17.9 \\
\hline $\begin{array}{l}\text { The instructors informed } \\
\text { me about my progress } \\
\text { periodically }\end{array}$ & 13.1 & 17.9 & 23.9 & 28.7 & 16.3 \\
\hline
\end{tabular}

Table 5 showed the results of key factors that determined the student satisfaction in distance learning education. Table demonstrated the results of independent variable that affect the dependent variable showed item/questions wise.

Results of independent variables are shown below:

\section{Conclusion}

The purpose of this research study was to understand the key factors affecting student satisfaction in distance learning. Researchers also collect information through primary data using a survey questionnaire distributed through email to all the students of VCOMSAT. From the literature review, it was found that in distance learning education, student satisfaction is based on instructor performance, student-instructor interaction, course evaluation, Learning management system use, instructor attitude, etc. From the literature review, we found that course evaluation and instructor performance is very important for student satisfaction in distance learning.
The researcher collects the primary data and analyzes the finding based on the questionnaire and found those students were very satisfied with instructor performance, course evaluation, and student-instructor interaction. It is also verified that there is a strong relationship between student satisfaction and independent variables instructor performance, course evaluation, and studentinstructor interaction. It is also concluded that male students are highly satisfied compare to female students. In the literature review, people perceived that distance learning is poor than traditional learning, but this study proved it wrong. Students are also satisfied with distance learning education because there is no need to attend classes physically, and students can continue to study with jobs.

\section{Recommendation}

There are some areas where future research is required in distance learning education.

- Researchers need to compare student's satisfactions with subject wise. Comparison of practical subjects and without practical subjects needs to identify with student satisfaction.

- There is also required to compare lecturer motivation with student satisfaction and performance.

- Future research is also needed to compare satisfaction of rural area and urban areas students in distance learning education and need to compare with traditional education.

- Most of the student especially in rural area does not know to use LMS and resources access therefore COMSATS VIRTUAL CAMPUS administration needs to launch one-week training before semester start in region basis physically. Therefore, COMSATS VIRTUAL CAMPUS can get more students in distance learning education.

\section{References}

About CIIT | COMSATS Institute of Information Technology, Virtual Campus. (n.d.). Retrieved March 05, 2016, from http://vcomsats.edu.pk/aboutus

Afzaal Ali \& Israr Ahmad, (2011). Key factors for determining students' satisfaction in distance learning courses: A study of allama iqbal open university. Contemporary Educational Technology, 2(2), 118-134.

Aixia, Ding, and Dan Wang (2011). Factors influencing learner attitudes toward E-learning and development of E-learning environment based on the integrated E-learning platform. International Journal of e-Education, e-Business, $e$ Management and e-Learning, 1(3), 264-68

Allen, I.E., \& Seaman, J. (2007, October). Online nation: Five years of growth in online learning.

American Distance Education Consortium (ADEC). (n.d.). Quality framework for online education. Lincoln, NE: Author. Retrieved December 28, 2008, from http://www.adec.edu/earmyu/SLOANC41.htm

Andersen, Jeffery C., (2013). Learner satisfaction in online learning: An analysis of the perceived impact of learner-social media and learner-instructor interaction . Electronic theses and dissertations. Paper 1115. http://dc.etsu.edu/etd/1115 
Anderson, Rolph E. (1973). Consumer dissatisfaction: The effect of disconfirmed expectancy on perceived product performance. Journal of Marketing Research, 10(1), 38-44

Anderson, T. (2003). Modes of interaction in distance education: Recent developments and research questions. In M. Moore (Ed.) Handbook of Distance Education, 129- 144. Mahwah, NJ.: Erlbaum.

Anderson, T. D. \& Garrison, D. R. (1995). Transactional issues in distance education: The impact of design in audio teleconferencing. The American Journal of Distance Education, 9, 27-45.

Arbaugh, J. B., \& Benbunan-Fich, R. (2007). The importance of participant interaction in online environments. Decision Support Systems, 43(3), 853-865.

Astin, A.W. (1993). What matters in college? Four critical years revisited. San Francisco: Jossey-Bass.

Banerjee, M. \& Brinckerhoff, L. C. (2002). Assessing student performance in distance education courses: Implications for testing accommodations for students with learning disabilities. Assessment for Effective Intervention, 27(3), 25-35.

Beaudoin, M. (1990). The instructor's changing role in distance education. The American Journal of Distance Education, 4(2), 26-34.

Benbunan-Fich, R., Hiltz, S. R., \& Harasim, L. (2005). The online international learning model: An integrated theoretical framework for learning networks. In S. R. Hiltz, R.G. Goldman (Eds.), Learning together online, 20-37. Mahwah, New Jersey:

Betts, K.S. (1998). An institutional overview: Factors influencing faculty participation in distance education in postsecondary education in the United States: An institutional study. Online journal of distance learning administration, 1(3). Retrieved January 1, 2009, from http://www.westga.edu/ distance/Betts13.html

Biggs, J. B. (1999). Teaching for quality learning at university. Buckingham: The society for research into higher education \& Open University press.

Bolliger, Doris U. (2004). Key factors for determining student satisfaction in online courses. International Journal on Elearning, 3(1), 61-67.

Bower, B.L. (2001). Distance education: Facing the faculty challenge. Online Journal of distance learning administration, 4(2). Retrieved January 1, 2009, from http://www.westga.edu/distance/ojdla/summer42/bower42.html

Boyd, D.M., \& Ellison, N.B. (2007). Social network sites: Definition, history, and scholarship. journal of computermediated communication, 13(1). Retrieved from http://jcmc.indiana.edu/vol13/issue1/boyd.ellison.html.

Chen, Chih-Ming, Hahn-Ming Lee, and Ya-Hui Chen (2005). Personalized e-learning system using item response theory. Computers \& Education, 44(3), 237-255.

Chiu, C., Hsu, M., \& Sun, S. (2005). Usability, quality, value and e-learning continuance decisions. Computers \& Education, 45, 399-416.
Needham, MA: Sloan-C. Retrieved December 28, 2008, from http://www.sloanconsortium.org/publications/survey/pdf/onlin e_nation.pdf 